\title{
Diagnosis or Risk Factors to Guide Statin Use?
}

Ann Fam Med 2014;12:iii. doi:10.1370/afm.1652.

$\mathrm{T}$ The Annals of Family Medicine encourages readers to develop a learning community of those seeking to improve health care and health through enhanced primary care. You can participate by conducting a RADICAL journal club and sharing the results of your discussions in the Annals online discussion for the featured articles. RADICAL is an acronym for Read, Ask, Discuss, Inquire, Collaborate, Act, and Learn. The word radical also indicates the need to engage diverse participants in thinking critically about important issues affecting primary care and then acting on those discussions. ${ }^{1}$

\section{HOW IT WORKS}

In each issue, the Annals selects an article or articles and provides discussion tips and questions. We encourage you to take a RADICAL approach to these materials and to post a summary of your conversation in our online discussion. (Open the article online and click on "TRACK Comments: Submit a response.") You can find discussion questions and more information online at: http://www.AnnFamMed.org/AJC/.

\section{CURRENT SELECTION}

\section{Article for Discussion}

Johansen ME, Green LA, Sen A, Kircher S, Richardson CR. Cardiovascular risk and statin use in the United States. Ann Fam Med. 2014;12 (3):215-223.

\section{Discussion Tips}

This study provides a chance to consider factors associated with taking statin drugs in a nationallyrepresentative sample of patients, and to consider the implications for our own prescribing practices.

\section{Discussion Questions}

- What question is asked by this study and why does it matter?

- How does this study advance beyond previous research and clinical practice on this topic?

- How strong is the study design for answering the question?
- To what degree can the findings be accounted for by:

- How patients were selected, excluded, or lost to follow-up? (How representative is this nationallyrepresentative survey?)

- How the main variables were measured?

- Confounding (false attribution of causality because 2 variables discovered to be associated actually are associated with a 3rd factor)?

- Chance?

- How the findings were interpreted?

- What are the main study findings?

- How comparable is the study sample to similar patients in your practice? What is your judgment about the transportability of the findings?

-What contextual factors are important for interpreting the findings? $?^{2-5}$

- How might this study change your practice? Policy? Education? Research?

- Who the constituencies are for the findings, and how they might be engaged in interpreting or using the findings?

- What are the next steps in interpreting or applying the findings?

- What researchable questions remain?

\section{References}

1. Stange KC, Miller WL, McLellan LA, et al. Annals Journal Club: It's time to get RADICAL. Ann Fam Med. 2006;4(3):196-197. http:// annfammed.org/cgi/content/full/4/3/196.

2. Stone NJ, Robinson J, Lichtenstein AH, et al. 2013 ACC/AHA Guideline on the treatment of blood cholesterol to reduce atherosclerotic cardiovascular risk in adults: a report of the American College of Cardiology/American Heart Association Task Force on Practice Guidelines. J Am Coll Cardiol. 2013;pii: S0735-1097(13)06028-2 [e-pub ahead of print].

3. Eckel RH, Jakicic JM, Ard JD, et al. 2013 AHA/ACC guideline on lifestyle management to reduce cardiovascular risk: a report of the American College of Cardiology/American Heart Association Task Force on Practice Guidelines. J Am Coll Cardiol. 2013; pii: S07351097(13)06029-4 [e-pub ahead of print].

4. Goff DC Jr, Lloyd-Jones DM, Bennett G, et al. 2013 ACC/AHA Guideline on the assessment of cardiovascular risk: a report of the American College of Cardiology/American Heart Association Task Force on Practice Guidelines. J Am Coll Cardiol. 2013 pii: S07351097(13)06031-2 [e-pub ahead of print].

5. Wenger NK. Prevention of Cardiovascular Disease: Highlights for the Clinician of the 2013 American College of Cardiology/American Heart Association Guidelines. [e-pub ahead of print]. Clin Cardiol. 2014. 